2006, and has made a serious and successful attempt to attract top researchers to Canada. It has also set its sights on bolstering applied research, an area in which Canada has been relatively weak.

Nonetheless, the critics' specific complaints do give cause for deep concern - which is borne out by a close look at the specifics of the Harper budget that was passed into law late last month. In an effort to funnel more research money to commercialization and to erase the Canadian deficit by 2015, the government plans to cut the Research Tools and Instruments Grants Program (RTI), the main equipmentfunding scheme for basic researchers, and to jettison the 24-yearold National Round Table on the Environment and the Economy (NRTEE), an independent source of expert advice to the government on sustainable economic growth. The government has also substantially weakened key laws that protect fish species and that require environmental assessments of development projects.

Of paramount concern for basic scientists is the elimination of the Can\$25-million (US\$24.6-million) RTI, administered by the Natural Sciences and Engineering Research Council of Canada (NSERC), which funds equipment purchases of Can\$7,000-150,000. An accompanying Can\$36-million Major Resources Support Program, which funds operations at dozens of experimental-research facilities, will also be axed. Canadian researchers have already warned the NSERC of 'drastic and irreversible' effects on the country's fundamental scientific research.

Even world-class facilities have not been spared. The government is closing the Polar Environment Atmospheric Research Lab (PEARL), located 1,100 kilometres from the North Pole and one of only three stations that keep a close watch on the polar atmosphere. The move comes just as data from the fast-changing Arctic climate are most needed. Another research station will be built to replace it, the government says, opening in 2017 - twice as far from the region it is supposed to monitor.

Equally disturbing is the proposed elimination next year of the internationally renowned Experimental Lakes Area (ELA) - a collection of

58 lakes and a field station in northwestern Ontario that has operated since 1968 as a natural laboratory. Work at the ELA has produced important evidence on the effects of acid rain and led to the discovery that phosphates from household detergents cause algal blooms. It has elucidated the impacts on fish of mercury and shown how wetland flooding for hydroelectricity leads to increased production of greenhouse gases.

It is hard to believe that finance is the true reason for these closures. PEARL costs the government about Can $\$ 1.5$ million a year, and the ELA Can $\$ 2$ million. The savings from eliminating the NRTEE would come to

"Scientific expertise and experience cannot be chopped and changed as the mood suits."
Can $\$ 5$ million - all from a total science and technology budget of some Can $\$ 11$ billion. Critics say that the government is targeting research into the natural environment because it does not like the results being produced.

Instead of issuing a full-throated defence of its policies, and the thinking behind them, the government has resorted to a series of bland statements about its commitment to science and the commercialization of research. Only occasionally does the mask slip - one moment of seeming frankness came on the floor of the House of Commons in May, when foreign-affairs minister John Baird defended the NRTEE's demise by noting that its members "have tabled more than ten reports encouraging a carbon tax".

Governments come and go, but scientific expertise and experience cannot be chopped and changed as the mood suits and still be expected to function. Nor can applied research thrive when basic research is struggling. If the Harper government has valid strategic reasons to undermine vital sectors of Canadian science, then it should say so - its people are ready to listen. If not, it should realize, and fast, that there is a difference between environmentalism and environmental science - and that the latter is an essential component of a national science programme, regardless of politics.

\section{London calling}

The battle for gold is about to begin - and science is taking its place behind the podium.

\section{A} s Nature went to press, excitement was mounting in the United Kingdom that Bradley Wiggins could become the first British cyclist to win the Tour de France this weekend. Win or lose, Wiggins will be back in the saddle a week or so later for the London Olympics - and he is already making headlines as he rebuffs Internet gossip that riders rely on performance-boosting drugs. "I cannot be doing with people [the critics] like that," was one of his more printable responses. "It justifies their own bone-idleness because they can't ever imagine applying themselves to do anything in their lives."

The use of drugs in sport and our inability to detect every case of misuse has an unfortunate side effect: the unfair suspicion that falls on those who win clean.

So, why bother? If we cannot ensure that everyone who competes is drug free, is one solution to remove the need for them to be so? That's one of a number of provocative ideas highlighted by a special series of Olympics-themed articles in this week's issue of Nature. (The opening ceremony next week, after all, will take place just a 5,000-metre race or so from our London headquarters.)

How much faster and stronger would an army of Olympians be if they were all allowed to get higher? And would medically supervised doping be safer? Some experts quoted in our News Feature on page 287 think so. One even goes so far as to call for a cross-sport 'prodoping' agency to invest in safer forms of enhancement. And why stop at chemical help? The future could see runners with bionic limbs and swimmers with feet made webbed by skin grafts - developments that could demand separate events, so great would the advantages be.

It may sound far-fetched, but according to a Comment piece on page 297, the Olympic playing field is already tilted towards those with "unearned advantages" over the rest: their genes. Enough common genetic ground has been found to link successful athletes, the article says, to ask whether the Olympics is merely a showcase for "hardworking 'mutants"'. If so, then would it be more sporting to hamper the lucky few - to make Usain Bolt run in heavy boots, say — or to cream the lot of them off into a separate competition entirely and leave the rest of us to have our mediocre fun?

For now, science remains a tool to catch those who break the existing rules, and to help those who want to play properly to compete. Profiles of some of the researchers who will work on these and other issues behind the scenes at London 2012 start on page 290. They include a psychologist who is working to assess intellectual disability in budding competitors in the Paralympics, and an epidemiologist waiting to map the inevitable spread of infectious disease among the several million expected visitors to London. Then there is the - unnamed - scientist who volunteered to be pulled through a swimming pool on a winch, subjected to a full body wax and then pulled through again, all to confirm what swimmers have long suspected, that body hair is a drag.

Finally, a Comment piece on page 295 examines the idea that humans evolved to run, and that a lifestyle without running could contribute to the modern boom in diseases such as obesity, diabetes and psychiatric disorders. Exercise doesn't just help muscles, it activates our brains. Armed with sticks and stones, our ancestors would $\rightarrow$ NATURE.COM To comment online, click on Editorials at: go.nature.com/xhunqu have to chase down prey for hours, until the animals collapsed. The best weapon, the article says, was endurance. Bradley Wiggins, and the plucky researcher in the swimming pool, would surely agree. 